\title{
PROJETO DE UM PARKLET COMO SOLUÇÃO PARA A IMPLANTAÇÃO DE PARACICLO NA UNIVERSIDADE REGIONAL DE BLUMENAU - FURB
}

\author{
Jonathan Mesquita Rodrigues (FURB); \\ Mako Alexandre Lisboa dos Santos (FURB) \\ Orientação: Valéria Ilsa Rosa, MSc. (FURB)
}

\section{INTRODUÇÃO}

Este texto traz um recorte de uma pesquisa desenvolvida num Trabalho de Conclusão de Curso (TCC) que teve como objetivo propor um produto que incentivasse a utilização de bicicletas, favorecendo a preservação do meio ambiente e a interação entre as pessoas.

A pesquisa resultou em um Parklet com $\mathrm{Pa}$ raciclo para servir de estacionamento. $\mathrm{O}$ local para implantação deste Parklet seria no Campus 2 da FURB - Fundação Universidade Regional de Blumenau/SC.

A pesquisa identificou questões específicas no campo da mobilidade no contexto de Blumenau/SC, procurando uma solução que fosse compatível com a realidade do público universitário, de modo a incentivar o uso das bicicletas no trajeto até a universidade e que promovesse a consciência da integração social, da preservação do meio ambiente e da reutilização de bens outrora descartados.

\section{PROCESSO CRIATIVO}

Para a definição da forma deste produto, buscou-se inspiração nas obras e trabalhos de Roberto Burle Marx, paisagista brasileiro reconhecido internacionalmente, alem de outras referências. As plantas utilizadas no paisagismo são as mesmas utilizadas no Jardim Suspenso da Empresa Companhia Hering em Blumenau/SC, projetado por Burle Marx.

A partir disso, partiu-se para o desenvolvimento criativo. O primeiro passo neste sentido foi o desenvolvimento de Painéis de referência, como o apresentado na Figura 1.

Além dos desenhos manuais e digitais necessários para o desenvolvimento deste produto, foi realizado um modelo volumétrico confeccionado na escala 1:10 que teve como função primordial a conferência das formas e da relação do produto com o usuário, realizada com auxílio de um boneco ergonômico articulado.

Na confecção do modelo foram empregadas chapas de MDF com espessura de $20 \mathrm{~mm}$ cortadas na máquina Router $\mathrm{CNC}$, coladas, lixadas e pintadas, conforme apresentado na figura 2.

O rendering digital (figura 3 ) foi realizado no software Solid Works e a inserção da vegetação e da representação dos usuários no contexto foi a partir do software Adobe Photoshop.

\section{O PRODUTO}

O projeto do Parklet prevê a utilização de madeira reaproveitada de pallets provenientes de 
Figura 1 a - Arte para o projeto do jardim do Palácio Capanema, de Roberto Burle Marx b - Foto do Jardim Suspenso da Cia. Hering, em Blumenau, de autoria de Roberto Burle Marx
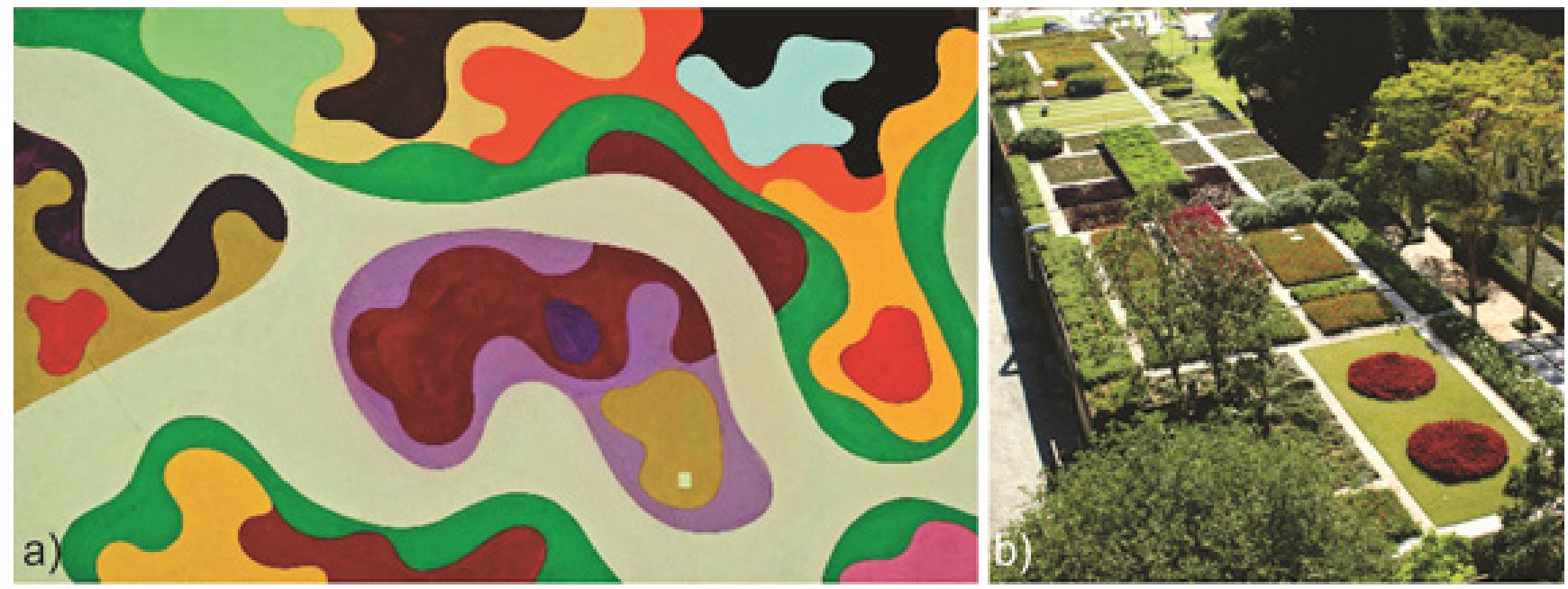

Fonte: Autores.

empresas da cidade que cederam o material para a universidade.

\section{CONCLUSÕES}

Entre outros aspectos, este trabalho apontou

Figura 2 - Confecção do modelo volumétrico. estresse causado pelo trânsito, visa ainda promover as relações interpessoais em um ambiente agradável ao ar livre, além da preservação ambiental por meio da reutilização de materiais que seriam descartados pelas indústrias.

Além de convidar os frequentadores a utilizarem a bicicleta servirá como local de convivência para os estudantes do campus 2, podendo ser adaptado e replicado em outros locais.

Dessa maneira, conclui-se que o Design, pode de fato, contribuir para uma verdadeira reformulação de conceitos que transcendem exclusivamente ao produto, destacando sua contribuição social para a melhoria da qualidade de vida das pessoas.

A pesquisa, assim como o projeto completo, podem ser conferidos na biblioteca virtual da FURB.

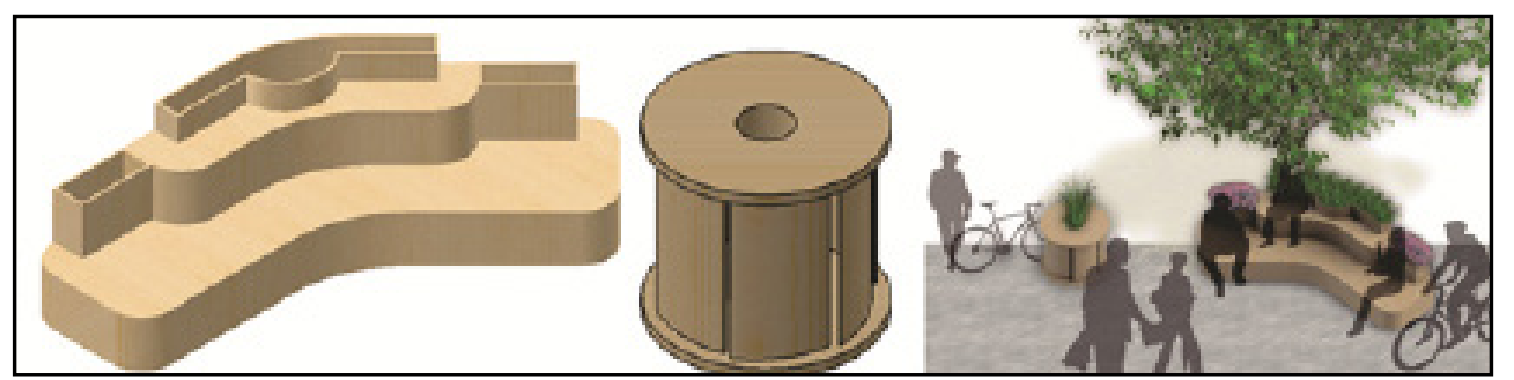

Fonte: Os autores, 2014. 